\title{
TANTANGAN MEWUJUDKAN LEMBAGA SYAREKAT ISLAM YANG RELEVAN DAN BERMUTU
}

\author{
Oleh : \\ Triwahyu Budiutomo \\ Universitas Cokroaminoto Yogyakarta
}

\begin{abstract}
Abstrak
Pendidikan merupakan sebuah indikator penting untuk mengukur kemajuan sebuah bangsa. Jika sebuah bangsa ingin ditempatkan pada pergaulan dunia dalam tataran yang bermartabat dan modern, maka yang pertama-tama harus dilakukan adalah mengembangkan pendidikan yang memiliki relevansi dan daya saing bagi seluruh anak bangsa. Trilogi Syarekat Islam : Sebersih-bersih Tauhid, Setinggi-tinggi ilmu dan Sepandai-pandai siasah tepat untuk dijadikan instrument dan aspirasi penegakan pendidikan yang bermartabat dan modern khususnya bagi sekolah-sekolah yang bernaung/memiliki ideology Syarekat Islam. Hubungan Aspiratif antar lembaga-lembaga Pendidikan, perlu ditingkatkan dan dioptimalkan dalam rangka membangun jejaring bagi peningkatan mutu lembaga-lembaga pendidikan Syarekat Islam. Perlu dibentuk Komisi Standard kurikulum, silabus dan buku ajar Ke-SI-an yang bermutu dan relevan dengan perkembangan jaman, dengan fokus membentuk karakter umat untuk berkehidupan masyarakat, bangsa dan negara yang Islami , harmonis moderat dan modern.
\end{abstract}

Kata Kunci: Tantangan, Syerikat Islam, Relevan dan Bermutu

\section{Pendahuluan}

Dalam perspektif politik pendidikan, seorang filosof yunani abad pertengahan mengatakan bahwa penaklukan dunia ditentukan oleh seberapa jauh pendidikan suatu bangsa dapat dicapai dan seberapa maju bangsa-bangsa bersangkutan menguasai ilmu pengetahuan, ini berarti sebagai symbol kemajuan peradaban bangsa, penguasaan ilmu pengetahuan menjadi sangat penting, bahkan Geertz menganggap penguasaan ilmu pengetahuan sebagai bentuk ekspresi kemajuan berpikir dan berperilaku sebuah bangsa. Pendidikan kita saat ini sedang menghadapi persoalan yang amat pelik, berbagai fenomena kehidupan mencerminkan adanya gejala semakin merosotnya moralitas dalam praktik bermasyaraka, berbangsa dan bernegara (Suyanto 2008 : 28 ). Dari berita diberbagai media cetak maupun elektronika, betapa mudahnya anggota masyarakat kita saat ini, tanpa rasa menyesal, berani melakukan perbuatan-perbuatan yang melanggar kaidah moral. 
Keadaan ini tentunya sangat ironis ketika kita melihat berbagai sumber nilai moralitas yang dalam tataran formal telah disepakati menjadi landasan kehidupan berbangsa dan bernegar seperti : Pancasila, UUD 1945 dan berbagai peraturan perundangan yng seharusnya menjadi sumber dan pengendali tegaknya nilai-nilai moral bermasyarakat, berbangsa dan bernegara Nilai-nilai luhur universal yang terkandung dalam Pancasila, beserta berbagai landasan hukum yang kita miliki ternyata belum efektif mengkondisikan bangsa kita yang memiliki praktik hidup bermasyarakat secara santun dan bermartabat. Pada masa lalu, sejarah bangsa Indonesia terutama pada masa perjuangan untuk memproklamirkan kemerdekaan Negara Republik Indonesia secara obyektif tidak mungkin bias mjenghapus atau menghilangkan eksistensi dan jasa-jasa yang telah dirintis olehy Syarekat Islam. Banyak tokoh-tokoh peregerakan dan perjuangan, termasuk Presiden Pertma Republik Indonesia, yang memperoleh pembinaan dalam lingkungan keluarga Syarekat Islam. HOS Tjokroaminoto. Ini Artinya. Syarekat Islam dengan tiga prinsip utama telah membuktikan berhasil menjawab tantangan jaman saat itu, Trilogi Sarekat Islam : (1) Sebersih-bersih Tauhid, (2) Setinggi-tinggi ilmu dan (3) Sepandai-pandai siasah.

Kondisi lembaga pendidikan Syarekat Islam dengan nama Lembaga Pendidikan Cokroaminoto. Pada saat ini telah ada lembaga pendidikan Syarekt Islam dari Lembaga Pendidikan Usia Dini (PAUD) sampai dengan Pendidikan Tinggi (PT), secara formal lembaga pendidikan tersebut berdiri sendiri-sendiri, umumnya hanya terikat secara aspiratif. Namun demikian dengan kekuatan aspirasi “ Trilogi Syarekat Islam “ lembaga-lembaga pendidikan tersebut masih dapat berdiri tegak. Aspirasi Syarekat Islam dilaksanakan melalui pemberian mata pelajaran/kuliah Ke-SI-an, Persoalannya, sampai saat ini belum ada kurikulum, silabus maupun bahan ajar yang standar, ini mengakibatkan mutu Ke-SI-an dapat dipertanggungjawabkan. Pertanyaan kita, bagaimanakah langkah-langkah kongkrit peningkatan mutu dan penerapan mata pelajaran/kuliah Ke-SI-an. Harapan kita akan terwujud manusia Syarekat Islam yang bermartabat dan modern ikut serta mewujudkan kehidupan bermasyarakat, berbangsa dan bernegara yang harmonis dan lebih baik. 


\section{Syarekat Islam}

Syarekat Islam mempunyai cita-cita untuk menegakkan Islam secara utuh sehingga terealisasikan syarikat Islam yang sedalam dan seluas-luasnya. Strategi pencapaian ini didasarkan pada tiga prinsip utama, yaitu : (1) Sebersih-bersihnya Tauhid; (2) Setinggi-tingginya ilmu dan Sepandai-pandainya siasah.

\section{Sebersih-bersihnya Tauhid}

Dalam segala sikap dan perilaku kita tidak mensekutuhan Tuhan kecuali Allah swt. Artinya, manusia syarekat Islam adalah manusia yang selalu menyadari diri bahwa semua yang dilakukan adalah ibadah atau pengabdian kepada Allah swt. Secara material maupun psikologis sikap perilaku ini akan selalu membuat rasa tenang danjh percaya diri dalam setiap perbuatan yang dilakukan, karena apa yang dilakukan dalam rangka ber " amal mahruf nahi munkar ".

\section{Setinggi-tingginya ilmu.}

Dalam pandangan syarikat Islam, menuntut ilmu adalah wajib. Inti dari asas ini adalah bahwa pendidikan Syarikat Islam memberikan keseimbangan pengajaran yang meliputi duniawi dan ilmu agama serta menitikberatkan pada pendidikan yang meningkatkan derajad kemanusiaan, Pendidikan syarekat Islam menekankan pada pembinaan karakter bangsa., melalui pendidikan yang berlandaskan trilogy Syarekat Islam diharapkan dapat memperluas wawasan dan meningkatkan ilmu yang memperkuat sebersih-bersihnya Tauhid. Semakin tinggi ilmu yang dimiliki seseorang makin kuat ke-Tauhid-an orang tersebut. Ilmu yang didapatkannya tidaklah hanya untuk memperluas wawasan diri sendiri tetapi untuk diamalkan demi kepentingan masyarakat, bangsa dan negara.

\section{Sepandai-pandai siasah.}

Sejak perintisannya Syarikat Islam tidak terlepas dari perjuangan berbangsa dan bernegara, kalau pada jaman sebelum kemerdekaan, Syarikat Islam memperjuangkan tercapainya kemerdekaan. Setelah kemerdekaan adalah mengisi kemerdekaan menuju tercapainya cita-cita bangsa dan negara adil makmur, aman dan sejahtera. Oleh karena itu, ilmu yang dikembangkan adalah ilmu

yang memperkuat ke-Tauhid-an dalam upaya mewujudkan cita-cita perjuangan kemerdekaan yaitu tercapainya cita-cita kemerdekaan.

Sebagaimana yang telah dilakukan para pendahulu dalam menyelesaikan berbagai permasalahan, maka dalam menyelesaikan berbagai permasalahan yang timbul saat ini harus juga dilakukan 
melalui siasah sesuai dengan situasi yang berkembang tetapi dengan tidak mengorbankan sikap sebersih-bersihnya Tauhid.

Ketiga prinsip utama Syarikat Islam adalah merupakan suatu kesatuan dalam arti tidak dapat dipisah-pisahkan. Sebersih-bersih Tauhid merupakan landasan semua pemikiran, sikap maupun perilaku manusia. Peningkatan ilmu merupakan upaya memperkuat Tauhid seseorang serta dalam menerapkan ilmu sebagai sebuah solusi keajiban manusia sebuah pencapaian citacita yang harus dilakukan melalui siasah yang tetap mendasarkan pada sebersih-bersihnya Tauhid, karena kesemuanya itu untuk meniungkatkan ke-Tauhid-annya. Trilogi Syarekat Islam sangat tepat diterapkan untuk mengatasi permasalahan merosotnya moral dan martabat serta menurunnya kehidupan bermasyarakat, berbangsa dan bernegara . denganh menerapkan ketiga prinsip utama tersebut diharapkan lembaga pendidikan khususnya yang beraspirasi Syarekat Islam akan mencetak Sumberdaya Manusia yang bersih Tauhidnya, tinggi ilmu dan pandai dalam menerapkan ilmu untuk kehidupan bermasyarakat, berbangsa dan berbegara yang lebih baik. Penerapan Trilogi Syarekat Islam dilakukan melalui pemberian mata pelajaran/kuliah KeSI-an. Artinya. Standardisasi dan peningkatan mutu kurikulum yang relevan dengan perkembangan jaman dapat dijadikan instrumen utama pendidikan Syarekat Islam.

\section{Lembaga-lembaga Pendidikan Syarekat Islam}

Kita ketahui, bahwa lembaga-lembaga pendidikan Syarekat Islam yang masih berdiri saat ini, dalam perkembangannya, berdiri sendiri-sendiri dengan nama lembaga Cokroaminoto ( SMA,SMK dan Universitas Cokroaminoto ). Lembaga-lembaga tersebut tidak terikat secara organisasi namun terikat secara aspiratif, mereka menerapkan aspirasi Trilogi Syarekat Islam dan terbukti masih dapat berdiri tegak. Ini adalah fenomena yang sangat menarik dan harus diapresiasi , bahwa peningkatan mutu dan relevansi Ke-SI-an merupakan langkah kongkrit dan bijaksana. Dan ini merupakan salah satu tugas Majelis Pendidikan Syarekat Islam yang bersifat amat segera, yaitu dengan membentuk Komisi Standar Kurikulum, Silabus dan Bahan Ajar Ke-Syarekat Islaman dan wajib diterapkan di seluruh Lembaga pendidikan yang memakai nama Syarekat Islam (Cokroaminoto), untuk selanjutnya Majelis pendidikan Syarekat Islam wajib selalu mengawasi dan meng " update" pelaksanaan mata pelajaran/kuliah Ke-SI-an. 


\section{Kesimpulan}

1. Trilogi Syarekat Islam : Sebersih-bersih Tauhid, Setinggi-tinggi ilmu dan Sepandai-pandai siasah tepat untuk dijadikan instrument dan aspirasi penegakan pendidikan yang bermartabat dan modern khususnya bagi sekolah-sekolah yang bernaung/memiliki ideology Syarekat Islam.

2. Hubungan Aspiratif antar lembaga-lembaga Pendidikan, perlu ditingkatkan dan dioptimalkan dalam rangka membangun jejaring bagi peningkatan mutu lembaga-lembaga pendidikan Syarekat Islam

3. Perlu dibentuk Komisi Standard kurikulum, silabus dan buku ajar Ke-SI-an yang bermutu dan relevan dengan perkembangan jaman, dengan fokus membentuk karakter umat untuk berkehidupan masyarakat, bangsa dan negara yang Islami, harmonis moderat dan modern

\section{Daftar Pustaka}

Djaja Saefullah, 2001, Syarekat Islam Pengembangan Pendid8kan Tinggi Islam Masa Depan, Kerta Kerja, UCY, Yogyakarta.

Suyanto, 2008, Dialog Interaktif, Multi Pressindo, Yogyakarta

Pendidikan Bermrtabat, Analisis KR 2007

Pendididkan dan Moralitas, Analisis KR 2007 